\title{
Heme and HO-1 inhibition of HCV, HBV, and HIV
}

\author{
Warren N. Schmidt ${ }^{1,2 *}$, M. Meleah Mathahs ${ }^{1,2}$ and Zhaowen Zhu ${ }^{1,2}$ \\ ${ }^{1}$ Department of Internal Medicine and Research Service, Veterans Affairs Medical Center, University of lowa, lowa City, IA, USA \\ 2 Department of Internal Medicine, Roy G. and Lucille A. Carver College of Medicine, University of lowa, lowa City, IA, USA
}

\section{Edited by:}

Mahin D. Maines, University of

Rochester School of Medicine, USA

Reviewed by:

Andrea Branch, Mount Sinai, USA

Curt Hagedorn, University of Utah

School of Medicine, USA

*Correspondence:

Warren N. Schmidt, Department of Internal Medicine, University of lowa Hospitals and Clinics, 200 Hawkins Drive, 4553 JCP, lowa City, IA 52242 USA.

e-mail: warren-schmidt@uiowa.edu
Hepatitis $\mathrm{C}$ virus, human immunodeficiency virus, and hepatitis $\mathrm{B}$ virus are chronic viral infections that cause considerable morbidity and mortality throughout the world. In the decades following the identification and sequencing of these viruses, in vitro experiments demonstrated that heme oxygenase- 1 , its oxidative products, and related compounds of the heme oxygenase system inhibit replication of all 3 viruses. The purpose of this review is to critically evaluate and summarize the seminal studies that described and characterized this remarkable behavior. It will also discuss more recent work that discovered the antiviral mechanisms and target sites of these unique antiviral agents. In spite of the fact that these viruses are diverse pathogens with quite profound differences in structure and life cycle, it is significant that heme and related compounds show striking similarity for viral target sites across all three species. Collectively, these findings strongly indicate that we should move forward and develop heme and related tetrapyrroles into versatile antiviral agents that could be used therapeutically in patients with single or multiple viral infections.

Keywords: Heme, viruses, HCV, HIV, HBV, metalloporphyrins, biliverdin, proteases

\section{INTRODUCTION}

Hepatitis C virus (HCV), Hepatitis B virus (HBV), and Human immunodeficiency virus (HIV) are three of the most common chronic viral infections worldwide. All of these viruses share common risk factors and modes of transmission including sexual, human blood product transfusion, and intravenous drug use (Koziel and Peters, 2007). In the decades following discovery and sequencing of all three viruses, there has been a constant medical need to update treatment regimens and employ new and more versatile antiviral agents. This review will focus on in vitro and molecular studies that have evaluated metalloporphyrins, specifically heme, and related derivatives, for their virucidal activity against the three viruses. What are emerging from these collective works are not only fascinating pictures of multiple viral targets to explain the antiviral activities of these metalloporphyrins, but there is also a promise that these compounds can be developed successfully into powerful, yet versatile antiviral agents.

\section{THE HEME AND HEME OXYGENASE SYSTEMS}

Heme (iron protoporphyrin IX) is the most common metalloporphyrin (MP) in eukaryotic cells and is essential for life. Heme is constructed from a highly conserved sequence of eight enzymatic reactions that sequentially link precursors into four pyrrole precursor rings to form the tetrapyrrole, protoporphyrin IX. In the final anabolic step, ferrous iron is inserted by the enzyme ferrochelatase to form heme or iron protoporphyrin IX (Figure 1; Heinemann et al., 2008). Heme is regularly complexed

Abbreviations: BR, bilirubin; BV, biliverdin; BVR, biliverdin reductase; FL, full length; HBV, hepatitis B virus; $\mathrm{HCV}$, hepatitis $\mathrm{C}$ virus; HIV, human immunodeficiency virus; HO, heme oxygenase; MP, metalloporphyrin; MPP, metalloprotoporphyrin; NS, non-structural; RT-PCR, reverse transcriptase polymerase chain reaction. into respiratory proteins such as hemoglobin and myoglobin to form a vital oxygen carrying and delivery platform. As a prosthetic group heme also performs essential activities for electron transfer and oxidation (Gray and Winkler, 1996). Because of the critical nature of all these basic activities, it is not surprising that virtually all steps of heme synthesis and degradation are tightly regulated with oxidative balance and many signaling pathways (Mense and Zhang, 2006).

Since the 1970s, commercial preparations of heme (Hemin and Panhematin), have been approved by the FDA for use in patients with acute porphyria. In addition to iron, natural metalloprotoporphyrins (MPP) and a variety of synthetic MP can complex other metals such as zinc, copper, cobalt, magnesium, manganese, tin, nickel, or chromium. Naturally occurring MPs serve as necessary co-factors for numerous oxygenases, peroxidases, and catalases. ZnPP, formed naturally during times of iron deficiency, is an excellent serum marker for iron deficiency anemia (Labbe, 1992) and has generated therapeutic interest for the treatment of jaundice of the newborn.

Initial catalysis of heme occurs via oxidation with heme oxidase (HO; Figure 2). The major isoforms of $\mathrm{HO}$ are $\mathrm{HO}-1$ and $\mathrm{HO}-2$. The role of HO-3 is not clear and is considered a pseudo transcript of HO-2 (Cruse and Maines, 1988; McCoubrey et al., 1997; Hayashi et al., 2004). HO-1 and HO-2 perform similar net enzymatic functions, yet only HO-1 is usually induced in response to cellular stressors such as hypoxia, cytotoxic agents, and infection (Immenschuh and Ramadori, 2000). HO opens the porphyrin ring of heme which is rate limiting for heme catabolism, and liberates equimolar ratios of $\mathrm{Fe}^{+2}$, carbon monoxide, and the linear tetrapyrrole biliverdin (BV). The reaction uses $3 \mathrm{~mol}$ of oxygen and reducing equivalents from NADPH: cytochrome P-450 (cytochrome $c$ ) reductase. BV is then rapidly converted to bilirubin (BR) by BV reductase (BVR). The entire sequence of heme oxidation and $\mathrm{BV}$ 


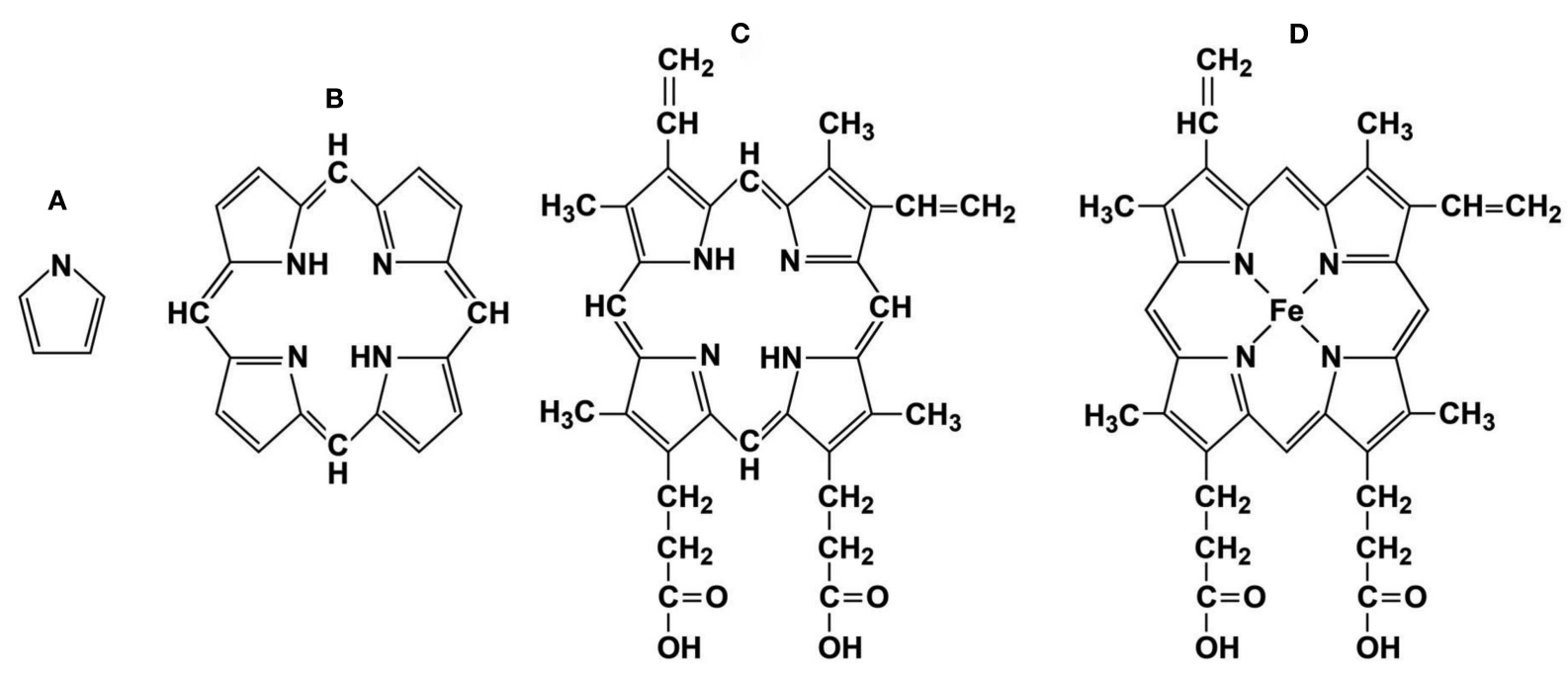

FIGURE 1 | Representative porphyrin structures. (A) pyrrole ring, (B) porphyrin ring, (C) protoporphyrin IX, and (D) Heme, iron protoporphyrin IX.

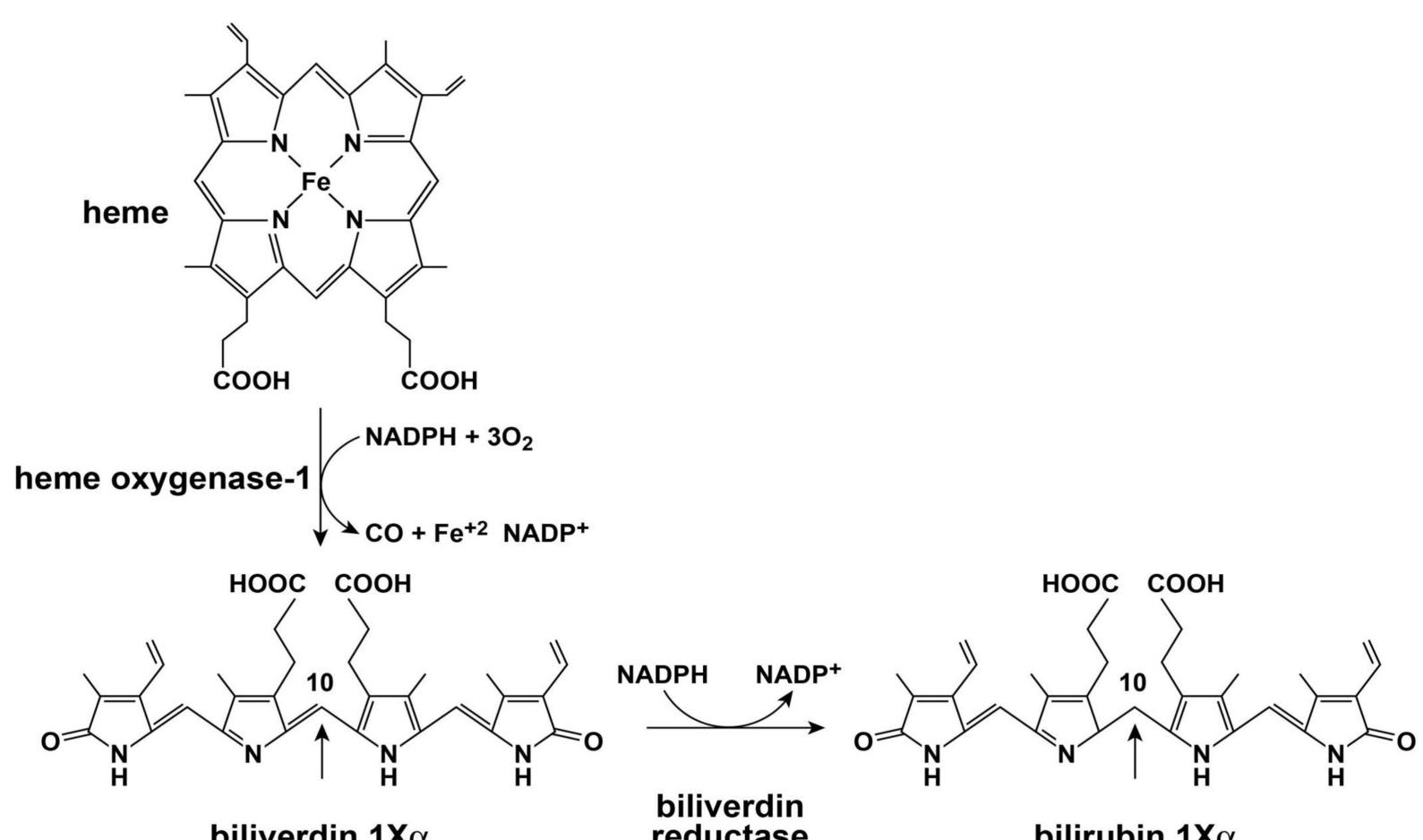

FIGURE 2 | Heme oxygenase and biliverdin reductase enzymes.

reduction likely takes place in synchrony upon a large complex of enzymes and co-factors that include HO, BVR, and NADPH (Ryter et al., 2006). BR and other tetrapyrrole derivatives are ubiquitous in nature and have a wide variety of functions in animals (McDonagh, 2001). Both HO-1 and BVR are highly inducible enzymes and respond to signaling and feedback in numerous cellular systems (Ryter et al., 2006; Kapitulnik and Maines, 2009). HO-1 induction provides important protection from oxidative stress and cellular damage (Abraham et al., 1995; Lee et al., 1996; Guo et al., 2001). Over the last two decades it is also becoming apparent that the precursors and catabolic products of the heme oxygenase system are capable of antimicrobial and antiviral activities. Of importance here, HO- 1 induction or overexpression promotes a wide range of antiviral activities for the major viral pathogens discussed in this review: HIV, HBV, and HCV (Devadas and Dhawan, 2006; Protzer et al., 2007; Shan et al., 2007; Zhu et al., 2008). 


\section{GENERAL CONSIDERATIONS OF VIRUCIDAL ACTIVITIES OF HEME AND RELATED COMPOUNDS}

Heme and structurally related MPs have actually generated interest as antimicrobials and antiviral agents for some time (Stojiljkovic et al., 2001). Porphyrins induce antiviral reactions through both non-specific and specific interactions with either host or virus which typically interfere with the viral life cycle. Typical nonspecific interactions include activities such as hydrophobic binding of the porphyrin with host cell membranes or viral envelope that inhibit viral binding and cellular entry. Generalized antiviral activities reflect the diversity of porphyrin structure as well as chemical complexity and versatility. Photoactive MPs absorb photons and partition into membranes to where they can exert a virucidal effect, especially with enveloped viruses as noted below.

In contrast, specific interactions of natural MPs appear highly dependent on structure and reflect the fact that the primary function of heme and similar MPs usually behave as crucial co-factors in specific oxidase and peroxidase reactions. Consequently, an emerging pattern suggests that natural MPs show more affinity and specificity for viral inhibition because they are the preferred cofactor for established cellular reactions that are metabolically protective for cellular stress which may also severely reduce viral fitness. This assertion is clearly tentative, however, and has not been formally studied.

Recently, a group of alkylated porphyrins was reported to inhibit hepadnaviruses, flaviviruses, filoviruses, and arena viruses (Guo et al., 2011). The antiviral effects of these compounds, or chlorophyllides (an alkylated porphyrin containing copper charged at neutral ph), were discovered by screening over 2,000 compounds for their ability to decrease HBV DNA in cultured cells. A derivative of chlorophyllide, the metal free chlorin e6a,was the most active compound of this group. Antiviral activity for other viruses such as HCV, HIV-1, Dengue (DENV-2), Marburg virus (MARV), Junin viruses (JUNV), and herpes simplex (HSV1) was also shown. Activity had high $\mathrm{EC}_{50}$ s in the low micromolar and nanomolar range for some viruses such as DENV and was selective for enveloped viruses. Non-enveloped viruses such as encephalomyocarditis (EMCV) and adenovirus (Ad) were highly resistant. The active porphyrin compounds caused disruption and dissociation of viral envelope proteins as assessed in a particle gel assay. These studies suggest use for these compounds as generalized virucidal agents for enveloped viruses.

Alternatively, an interesting antiviral application of some photoactive MPs has been studied for non-enveloped viruses such as Hepatitis A virus (HAV). HAV is a small picornavirus that is orally transmitted from fecal contaminated water and food. Like all picornaviruses (the family includes notable human pathogens such as polioviruses, enteroviruses, and rhinoviruses) the nonenvelope structure of HAV presents challenges for prevention of infection because of its small size and resistance to inactivation. These viruses are highly resistant to common bacterial filtration techniques and the protein capsid renders the virus more resistant to chemical disinfection (Lemon et al., 1994). Casteel et al. (2004) showed that synthetic porphyrins could photo-inactivate HAV in plasma and other body fluids. Consequently, synthetic porphyrins may offer an effective and relatively safe approach to disinfection of non-enveloped viruses in various types of aqueous media.
Potentially, this remarkable property could widely influence the epidemiology and pathogenesis of a variety of common pathogens that cause considerable morbidity and mortality worldwide.

Song et al. (1997) assessed the anti-HIV properties of various water-soluble polysulfonated and polycarboxylated porphyrins and their metal (Mn, Fe, and $\mathrm{Ni}$ ) derivatives against HIV-1, HIV2 , and simian immunodeficiency virus infection in MOLT4 target cells. Some of these compounds were potent inhibitors of HIV infection and they likely interfere with the binding of HIV protein gp120 to the CD4 cellular receptor. Specific antibody studies demonstrated that the porphyrins directly bound to the gp 120 protein to inhibit formation and uptake of gp 120 and CD4+ T cell receptor binding complex. Interestingly, the gp 120 protein was also the probable binding site of a group of boronated porphyrins and other related MPs that were reported to bind gp120 and inhibit infection of CD4+ T cell line MT-2 (Debnath et al., 1994, 1999).

The antiviral activities of some more specialized synthetic porphyrins and derivatives against HCV have also been studied recently (Cheng et al., 2010). These workers evaluated structureactivity relationships of synthetic tetraphenylporphyrins and their anti-HCV properties as a proof-of- concept model for the development of proteomimetics in HCV drug discovery. Nanomolar levels of a biphenyl porphyrin derivative were noted to be the most potent inhibitor of full length Con1 replicons (Blight et al., 2002) but were less active for genotype $2 \mathrm{a}$ (JFH-1) subgenomic replicons (Kato et al., 2003). Furthermore, the porphyrin showed synergistic antiviral activity when incubated with replicons together with a known HCV protease inhibitor BILN 2061 as well as the antiviral cytokine $\alpha$-interferon-2a. While the cellular targets for the porphyrin derivatives are not yet clear, these studies demonstrate that the tetraphenylporphyrin backbone is a useful scaffold on which to hang a variety of chemical groups and define structure-function relationships for additional antiviral development.

\section{DIRECT EFFECTS OF HEME AND RELATED COMPOUNDS}

Direct interactions of heme and related MPs are important medically for the development of new and improved antiviral agents against $\mathrm{HIV}, \mathrm{HBV}$, and $\mathrm{HCV}$ in addition to other human pathogens that cause persistent infection and chronic disease. Viral targets might include any of the key steps in a virus' life cycle such as entry, replication, assembly, and exit from the host cell. Alternatively, interactions of MP that enhance pathogen recognition and immune response pathways would be expected to decrease viral fitness and replication mechanisms. In this regard, heme and related natural compounds have recently been shown to possess astonishingly specific antiviral protease and polymerase activities for both human hepatotrophic and HIV viruses. As discussed below, an emerging pattern demonstrates novel actions of heme that influence not only viral replication, but immune recognition, inflammation, primary interferon responses, apoptosis, and oxidative defense mechanisms.

\section{ACTIONS ON SPECIFIC VIRUSES HEPATITIS C VIRUS}

Hepatitis C virus is a small enveloped RNA virus and occupies a single genus of Hepacivirus of the Flaviviridae family. This 
family also includes such human pathogens as yellow fever and dengue. HCV has a plus-stranded RNA genome with a single long open-reading frame that is translated into a large polyprotein, then processed by host and viral proteases (Lindenbach and Rice, 2005). The non-structural (NS) proteins NS3/4A protease, NS5B RNA dependent RNA polymerase (RdRp) and the NS5A protein, necessary for replication, have been the targets of intense research efforts to develop new antiviral drugs (Soriano et al., 2009). The ability to study the HCV life cycle and develop anti-HCV agents was initially hampered for nearly a decade by the inability to grow and pass the virus in cell culture or small animal models. However, viral replicon models began to appear by 1999 (Lohmann et al., 1999; Pietschmann et al., 2001; Blight et al., 2002) and these constructs enabled high throughput in vitro testing for a wide variety of potential antiviral drugs. In addition to replicons, defined infectious strains (Cai et al., 2005; Wakita et al., 2005) and patient wild type viruses (Castet et al., 2002; Gondeau et al., 2009) have been passed in primary hepatocytes and other permissive cell lines. Recently, reliable chimeric mouse-human models for in vivo testing of antiviral activity have also been introduced (Bissig et al., 2007, 2010; de Jong et al., 2010; Washburn et al., 2011).

\section{DIRECT ANTIVIRAL EFFECTS OF HEME AND DERIVATIVES ON HCV}

Indications that heme and its enzymatic products may interact with HCV actually arose from assays of human liver slices collected from HCV infected patients. Abdalla et al. (2004) evaluated relative expression of oxidative defense enzymes in infected patient liver samples as compared to uninfected control liver. HO-1 was dramatically reduced in HCV infected liver, in contrast to other antioxidative enzymes, catalase, CuZn and Mn super oxide dismutases which all remained unchanged. Furthermore, immunohistochemistry confirmed that the reduction of HO-1 expression was limited to hepatocytes, the site of HCV replication, and not Kupffer cells. Since chronic HCV infection causes hepatic inflammation and progressive fibrosis, HO-1 downregulation was quite unexpected as it might be anticipated that the enzyme would be induced as in other liver diseases (Makino et al., 2001; Bauer et al., 2003). Moreover, in the same study, autoimmune hepatitis and chronic HBV showed marked HO-1 upregulation in affected hepatocytes (Abdalla et al., 2004). These findings suggested that the virus can specifically modulate HO-1 expression although reasons for this behavior were not apparent at the time. Nevertheless, reduction of this important oxidative defense enzyme in the hepatocyte may indirectly contribute to progressive oxidative injury and facilitate fibrosis. In fact, later experiments demonstrated that overexpression of HO-1 in replicon cells promoted increased resistance to oxidant-induced cytotoxicity (Zhu et al., 2008).

Ensuing work by a number of groups has revealed dramatic innate anti-hepatitis $\mathrm{C}$ activities for heme and the oxidative products of the heme oxygenase system. It was first demonstrated that iron can inhibit the HCV NS5B RdRp by high affinity $(\mathrm{Kd}=-6 \mu \mathrm{M})$ binding to the divalent cation binding pocket of the polymerase (Fillebeen et al., 2005). The Kd for ferrous ion was found to be 500 times greater than the preferred $\mathrm{Mg}^{+}$ion. Either divalent $\mathrm{Mg}$ or $\mathrm{Mn}$ is absolutely required for NS5B enzymatic activity (Ferrari et al., 1999; Bougie et al., 2003; Benzaghou et al., 2004). Antiviral activity of free iron has been confirmed by others (Yuasa et al., 2006; Zhu et al., 2008). However, free iron also induces HO-1 suggesting that the virucidal activity of Fe is likely more complicated than just binding and inactivating the polymerase (Hou et al., 2009). Iron would also be an unlikely choice as a therapeutic agent for HCV since it is usually considered to be a hepatotoxin (Ryter and Tyrrell, 2000) and it seems doubtful whether sufficient intracellular levels of free iron might be achieved in vivo to be useful therapeutically without causing cellular injury. Mild iron accumulation in HCV infected human liver samples has been correlated with more severe liver disease in some but not all studies (Beinker et al., 1996; Kayali et al., 2005, 2007). Some but not all earlier clinical studies with $\alpha$-interferon treatment regimens suggested that phlebotomy could improve viral clearance and increase sustained virological responses to $\alpha$-interferon (Di Bisceglie et al., 2000; Fontana et al., 2000; Desai et al., 2008). Finally, some of the experiments looking at the effects of iron on replication in vitro were actually performed using hemin to load cells with iron instead of iron salts (Fillebeen et al., 2005, 2007). Consequently the potency of free iron may have been overestimated since more recent studies have shown that heme as well as its initial oxidation product biliverdin can also directly inhibit the HCV NS3/4A protease (Zhu et al., 2010a).

As noted above, earlier work demonstrated that BV and bilirubin (BR) were able to inhibit the aspartyl protease of HIV (McPhee et al., 1996). In contrast, HCV NS3/4A protease is serine activated with a classical common catalytic mechanism like other members of this large class of proteolytic enzymes (Love et al., 1996; Yan et al., 1998). Inhibition of serine activated proteases with a tetrapyrrole appears common as a recent study demonstrated that both BV and BR were capable of inactivating intestinal trypsin and chymotrypsin (Qin, 2007). In this regard, Zhu et al. (2010a) reported that BV, heme, and to a much lesser extent BR were able to attenuate HCV replication in NS and full length replicons in vitro. BV was found to be a potent inhibitor of recombinant NS3/4A protease using Fluorescence Resonance Energy Transfer (FRET) inhibition assays in contrast to BR (Figure 3). After testing a number of biologically relevant linear tetrapyrroles, $\mathrm{BV}$ showed the lowest $\mathrm{IC}_{50}$ of all compounds tested $(9.3 \mu \mathrm{M})$ and was considerably more potent than its reduction product, BR (Figure 3A). Assays conducted in the presence of both BV and AnaSpec \#25346, a known commercially available inhibitor, showed an additive effect. Lineweaver-Burk plots indicated a mixed competitive and non-competitive inhibitory mechanism $\left(K_{\mathrm{i}}=0.6 \mu \mathrm{M}\right.$ and $\left.K_{\mathrm{i}}^{\prime}=1.1 \mu \mathrm{M}\right)$. Taken together, the kinetic experiments suggest there is associated non-competitive protease inhibition that probably occurs in an allosteric fashion and requires further study.

The marked difference in the avidity of BV and BR for the HCV NS3/4A protease may be explained by differences in structure and physical chemistries of the two linear tetrapyrroles. BV and BR have widely different secondary structures [see McDonagh, 2001 for review] in spite of the fact that they differ only by a double vs. single $\mathrm{C}-\mathrm{C}$ bond at the 10 "hinge" position respectively (Figure 2). The hinge double bond restrains BV into a flat rather fixed limited plane. In contrast, the free rotation about the hinge single bond of BR allows internal hydrogen bonding of the $\mathrm{COOH}$ 

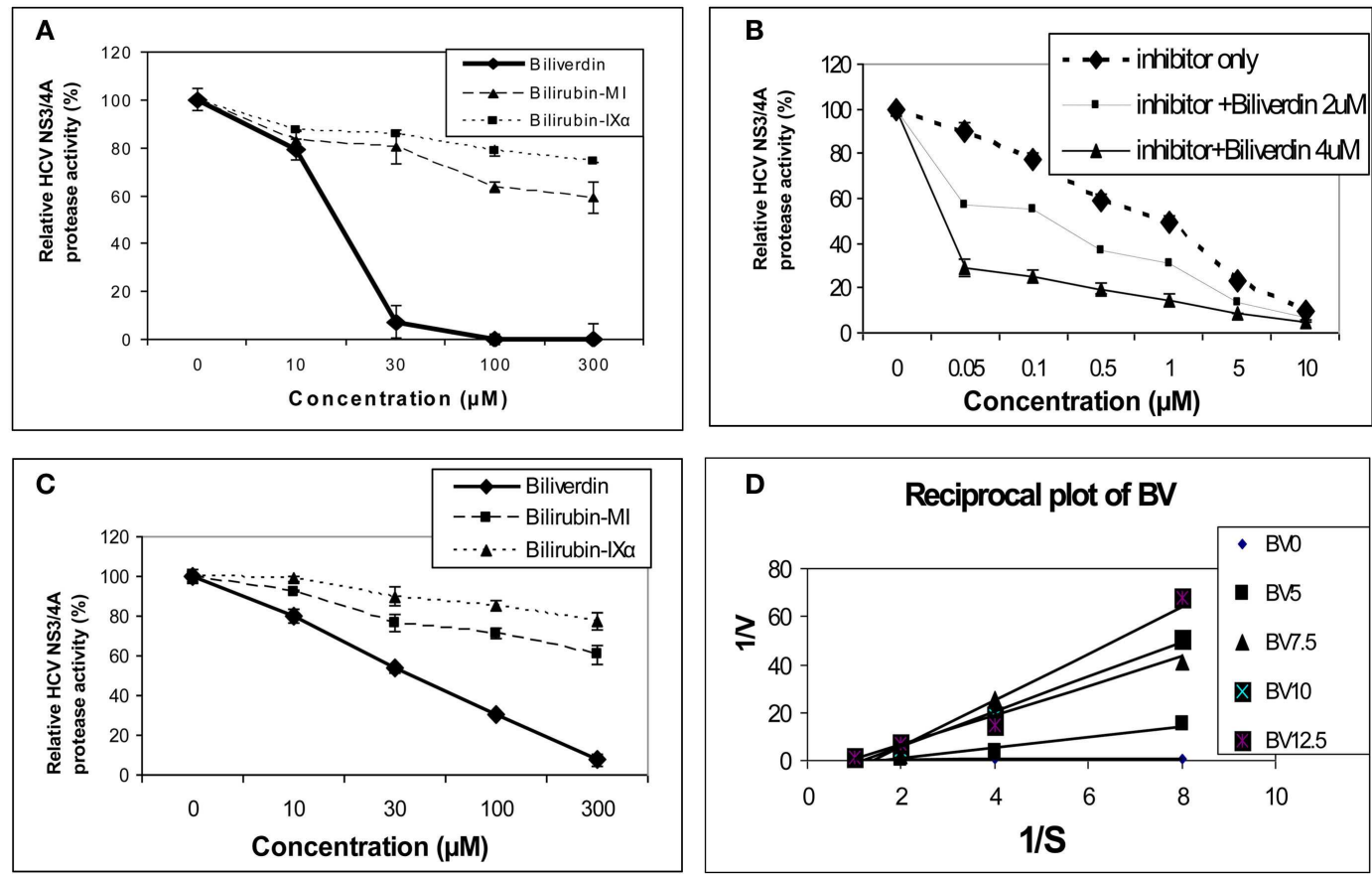

FIGURE 3 | Tetrapyrrole inhibition of HCV NS3/4A protease. (A,B) Protease activity was determined fluorometrically (FRET assay) using recombinant NS3/4A enzyme and various concentrations of inhibitors. (C) Endogenous NS3/4A protease activity in microsomes of replicons was measured using the same FRET assay but employing endogenous, partially purified NS3/4A protease from replicon cells (Zhu et al., 2010a). (D) Reciprocal (Lineweaver-Burk) plot of substrate concentration vs. enzyme activity. Recombinant protease activity was determined fluorometrically. Each point is the mean \pm SEM of 3-5 determinations groups which folds the molecule into a hydrophobic "ridge-tile" structure (Nogales and Lightner, 1995). The NS3/4A protease has an unusually long and shallow active site groove that is quite atypical for serine activated proteases (Love et al., 1996). Presumably, the active site accommodates the flat BV molecule to allow stable occupation while the bulky hydrophobic BR fits poorly. Presently, it is unclear which functional groups interact with the serine active site triad and where potential allosteric sites may be located. However, these interactions appear important for future drug design of tetrapyrroles as antiviral agents.

At first we attributed the antiviral activity of heme to its induction of HO-1 and rapid oxidation with liberation of free iron and BV. However, direct testing of heme against the recombinant $\mathrm{HCV}$ $\mathrm{NS} 3 / 4 \mathrm{~A}$ protease in the FRET assay has revealed that heme, like $\mathrm{BV}$, is also a direct protease inhibitor. Furthermore, some related metalloprotoporphyrins (MPP) such as $\mathrm{ZnPP}$, also showed potent antiprotease and antiviral activities in vitro which occurred at quite similar inhibitor concentrations (Figure 4; Zhu et al., 2011). Further studies looking at relationships between tetrapyrrole structure, HCV protease binding affinity, and antiviral activity are ongoing in our laboratory. However, as noted above, planar compounds such as metal protoporphyrins appear to bind protease tightly in contrast to folded structures such as bilirubin derivatives, conjugated bilirubins, and mesoporphyrins (Zhu et al., 2010a). per point. Plot of [BV] vs. either 1Nap or $\mathrm{Km} N$ (not pictured) showed highly significant linearity $(r=0.975$ and $r=0.979$ respectively, $p<0.005$ ) indicating mixed inhibition of NS3/4A protease by BV ( $K_{\mathrm{i}}^{\prime}=1.1 \mathrm{mM}$ and $K_{\mathrm{i}}=0.6 \mathrm{mM}$, respectively). 0 to the commercial Inhibitor $=$ NS3/4A protease competitive inhibitor, AnaSpec \#25346. Biliverdin $=>99 \%$ Biliverdin IX- $\alpha$. Bilirubin-mixed isomers $(\mathrm{MI})=93 \%$ Bilirubin IX- $\alpha$, and $6 \%$ associated Bilirubin isomers. Bilirubin $\mid X-\alpha=>99 \%$ bilirubin IX- $\alpha$. (With permission Zhu et al., 2010a see original manuscript for further details.)

Porphyrins with structures related to heme and $\mathrm{ZnPP}$, such as the meso derivative ZnMP, have also been shown to have antiviral actions through HO-1 induction, however, with a more indirect mechanism. Transcriptional activation of HO-1 depends, in part, on Bach 1 a negative repressor of the HO-1 promoter region (Ogawa et al., 2001; Kitamuro et al., 2003). ZnMP was shown to induce the degradation of Bach 1 protein through increased proteasome degradation thus alleviating $\mathrm{HO}-1$ promoter repression, facilitating $\mathrm{HO}-1$ induction, and subsequent reduction of $\mathrm{HCV}$ RNA in NS replicons (Hou et al., 2008). Furthermore, a follow up study from the same group demonstrated that ZnMP could target HCV NS proteins such as NS5A for proteasomal degradation through ubiquitination (Hou et al., 2010).

\section{INDIRECT ANTI-HCV EFFECTS OF HEME AND DERIVATIVES}

Other reasons for the antiviral activity of heme and related molecules have also been investigated. Lehmann et al. (2010) reported that BV induced type I interferon expression in replicon cells which was accompanied by expression of interferon stimulated gene products. While this study was the first to describe direct interaction of an important natural tetrapyrrole with the innate immune system, the mechanism is not yet clear (Lehmann et al., 2010). Primary induction of interferon by $\mathrm{BV}$ in vitro has not been reported previously and appears contrary to the known anti-inflammatory 


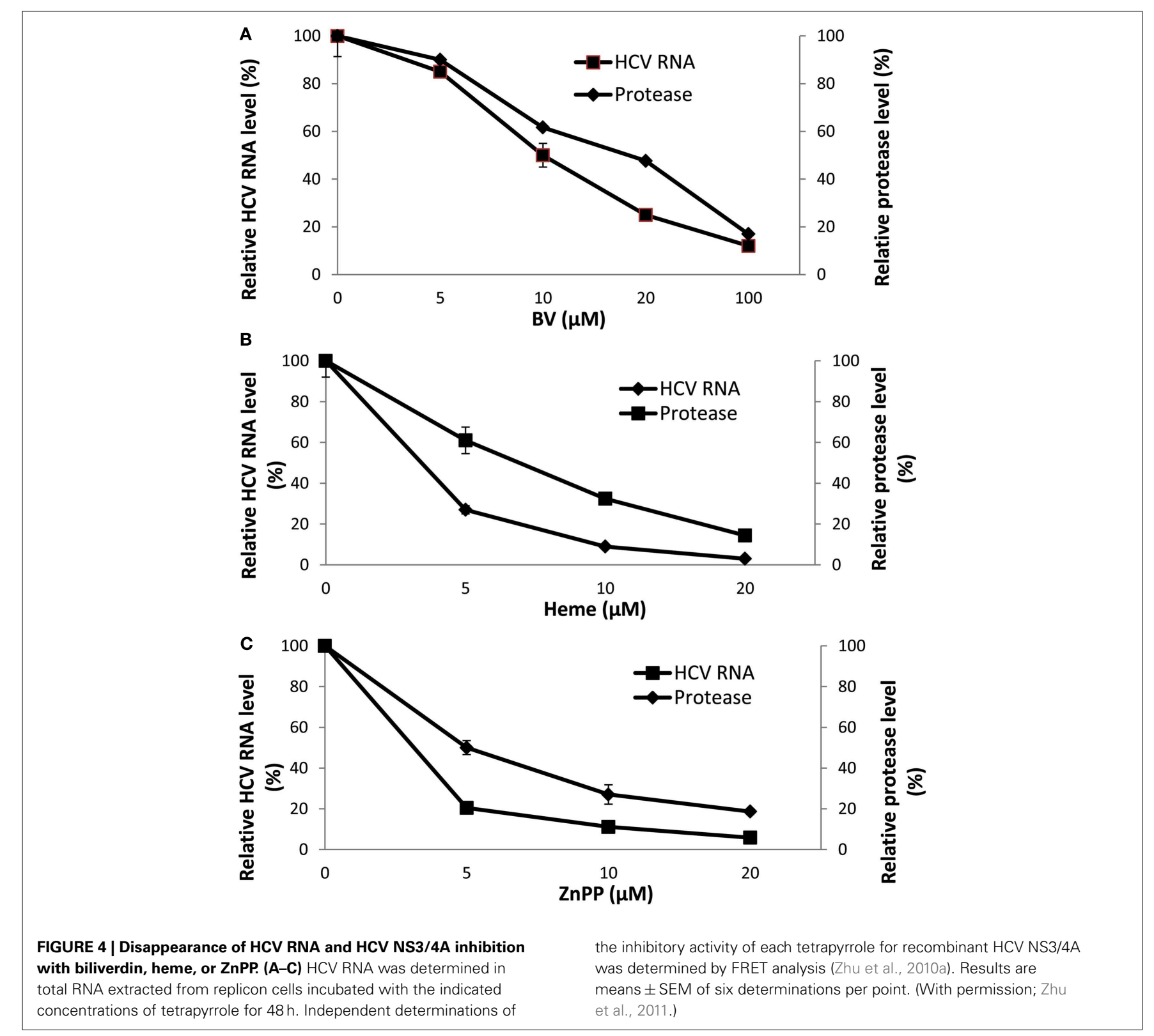

character of BV and HO-1 induction. BV has been shown to induce nuclear accumulation of biliverdin reductase which then decreases nuclear NFkB in Hek293 cells (Gibbs and Maines, 2007; Gibbs et al., 2010). The latter findings are consistent with an immunosuppressive role for BV (Ollinger et al., 2007) in contrast to the more pro-inflammatory properties of heme (Gozzelino et al., 2010). On the other hand, in other cell types such as human myeloid cells, HO-1 induction was noted to be essential for IRF3 and NFkB activation and nuclear accumulation which are prerequisites for type I interferon induction (Tzima et al., 2009; Kalliolias and Ivashkiv, 2010). HO-1 knockout mice demonstrated that HO- 1 induction is necessary for early phase activation of the innate immune sensing pathways TRIF-IRF3 and RIG-I-IRF3 with Sendai virus for the production of $\beta$-interferon and other primary response cytokines (Tzima et al., 2009; Koliaraki and Kollias, 2011). It is not known whether an HO-1 enzymatic product or a secondary mediator is required for these activities or whether they occur in other cell types such as hepatocytes. Nevertheless, these findings expand the influences of HO-1 into innate immunity and potentially other related pathways.

\section{BV AND HEME CAN REVERSE HCV NS3/4A INHIBITION OF TYPE I INTERFERON INDUCTION}

As is typical of viral pathogens, the NS3/4A protease has extra viral proteolytic activities that serve to increase the efficiency of viral infection and evasion of host immune system. NS3/4A can cleave pattern recognition receptors (PRR) or their interface adapter proteins within type I interferon signaling pathways and thus disable transcriptional induction of $\alpha$ and $\beta$ interferon (Li et al., 2005b; Meylan et al., 2005; Loo et al., 2006; Bode et al., 2007; Kalliolias and Ivashkiv, 2010). The two best studied induction pathways likely important for HCV responses are those that recognize intracellular 
double stranded (ds) RNA and include the Toll like receptor 3 (TLR3) and the Retinoic acid inducible gene-1 (RIG1) pathways. HCV NS3/4A cleaves specific adapter proteins of both pathways including TRIF of the TLR3 system and Cardiff of the RIG1 system (Figure 5; Li et al., 2005b; Meylan et al., 2005; Bode et al., 2007). Knowing that heme and other tetrapyrroles inhibit the HCV protease, we recently investigated whether these compounds would restore type I interferon induction after disruption of interferon signaling with the protease.

Clonal cell lines of Huh 7 such as Huh7.5 and Huh 515 are known to have poor dsRNA and dsDNA innate immunity recognition which is a likely reason that they are permissive for $\mathrm{HCV}$ replication (Li et al., 2005a; Cheng et al., 2007). Consequently, to evaluate the effects of heme on type I interferon signaling, it was necessary to construct a reconstituted model system. Hek293 cells were chosen because they are known to have relatively intact innate immune recognition and high transfection efficiency (Khvalevsky et al., 2007). We transfected dsRNA antigen into Hek293 cells and $48 \mathrm{~h}$ later assessed interferon induction using luciferase reporter gene constructs containing promoter regions for $\beta$ interferon. Transfection of dsRNA elicited robust induction of type I interferon, however, this was clearly attenuated when cells were co-transfected with NS3/4A expression vectors (Figure 6). In contrast, incubation with heme or BV significantly restored induction in the presence of protease and depending on protease and substrate concentrations, this was nearly complete in some cases (Figures 6A,B; Zhu et al., 2011). Additionally, restoration of interferon induction in the presence of protease was sharply accompanied by induction of interferon stimulated response gene (ISRG) products such as OAS-1 as shown here (Figures 6C,D; Zhu et al., 2011). Furthermore, we noted that BV or heme only controls without protease, showed little ability to augment type I interferon induction when incubated with cells either with or without dsRNA antigen. This suggests that in the present system the tetrapyrroles are unlikely to induce type I interferons as a primary antiviral mechanism. Nevertheless, these data expand the capabilities of heme and similar tetrapyrroles to promote beneficial effects for the innate immune system.

\section{HUMAN IMMUNODEFICIENCY VIRUS}

Human Immunodeficiency virus is a human pathogenic RNA retrovirus of the genus Lentivirus first identified in the early 1980s (Barresinoussi et al., 1983; Popovic et al., 1984) and found worldwide. HIV is not a hepatotrophic virus, however as noted

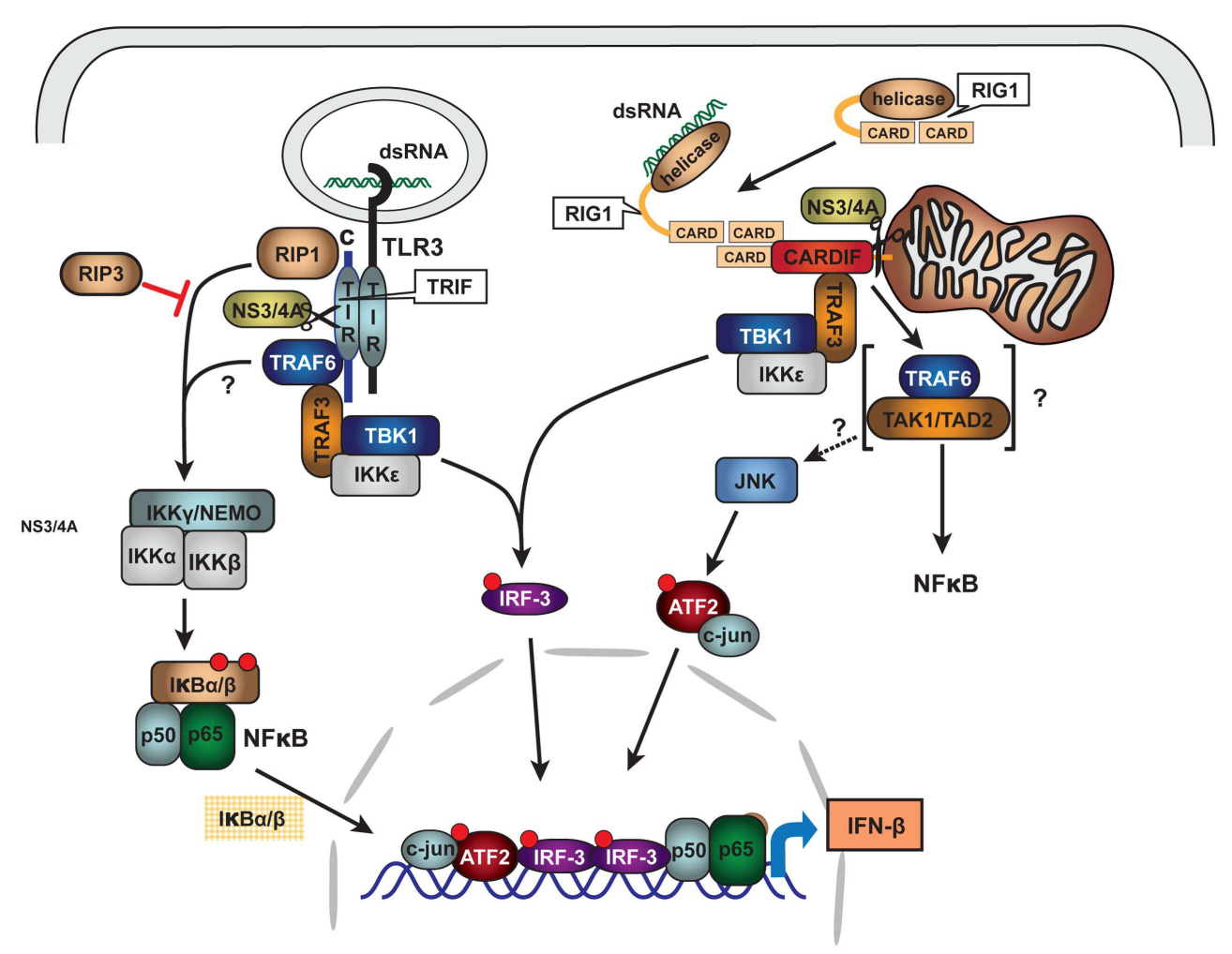

FIGURE 5 | Schematic of HCV NS3/4A protease inhibition of innate immune signaling pathways: TLR3 and RIG1. Double stranded RNA (dsRNA) viruses or viruses with dsRNA intermediate activate innate immune system signaling pathways for type I interferon induction through binding to Pattern Recognition Receptors (PRR). For HCV, PRR are associated with at least two major signaling pathways: TLR3 and RIG1. Upon intracellular binding of dsRNA to associated adapter proteins TRIF and CARDIFF, respectively, signaling is transmitted through complex intermediate steps of recognition, binding, and phosphorylation leading to activation of the transcriptional factors IRF3 and NFKB. The activated nuclear transcription factors bind to type I interferon promoters and induce $\alpha / \beta$-interferon transcription. HCV NS3/4A protease is known to cleave both TRIF and CARDIFF adapters thus crippling innate immune antigen recognition and signaling for type I interferon induction. With permission (Bode et al., 2007), see original review for terminology and abbreviations. 


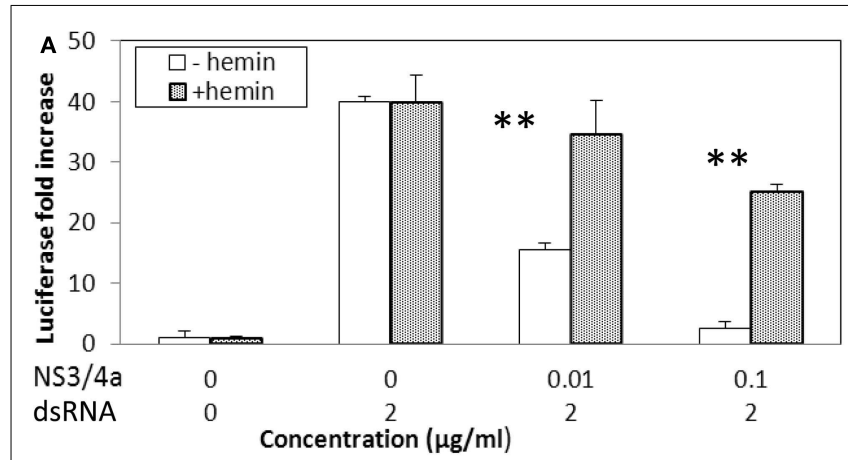

C

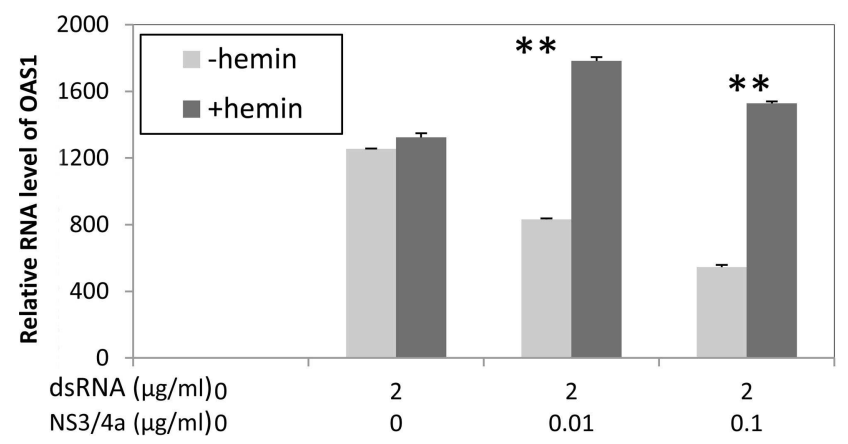

FIGURE 6 | Biliverdin and Heme can restore IFN promoter activation and Interferon Stimulated Response Genes (ISRG) after interference of IFN signaling with HCV NS3/4A. (A,B) HEK 293 cells were

transfected with dsRNA and vectors containing Type I IFN promoter-luciferase construct and complete NS3/4A sequence plasmid construct or control plasmid. Cells were then incubated with heme $(20 \mu \mathrm{M})$ or Biliverdin $(50 \mu \mathrm{M})$ for $48 \mathrm{~h}$. Cellular lysates were prepared and assayed for interferon promoter activation using luciferase assay (Zhu et al., 2010b). Each point is the mean of six determinations (two separate
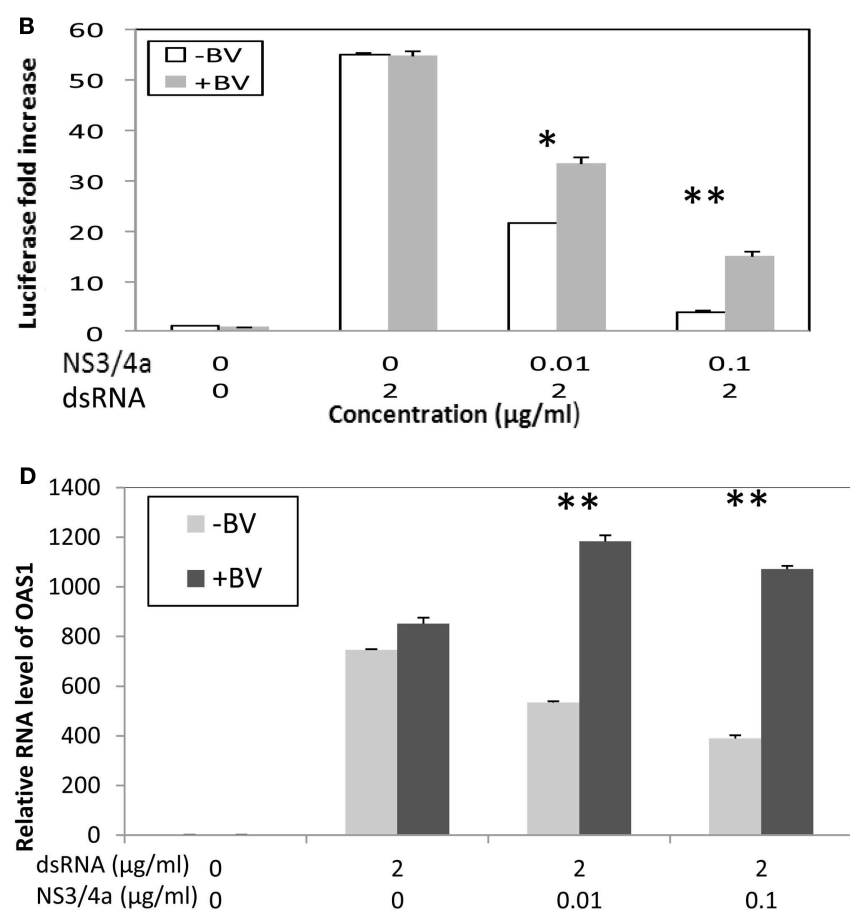

cell culture incubations, and then three replicates for luciferase assay per incubation). (C,D) Parallel experiments showing that heme and BV can restore interferon stimulated response genes (ISRG) after inhibition with NS3/4A protease. HEK 293 cells were transfected with dsRNA with or without HCV NS3/4A plasmid then incubated with heme or BV for same time and concentrations as (A,B) OAS-1 mRNA was measured using Real Time RT-PCR. Each point is the mean of six determinations as described for $(\mathbf{A}, \mathbf{B}){ }^{*} p<0.01 ;{ }^{*} p<0.05$; NS, not significant. (With permission Zhu et al., 2011.) previously, a high percentage of patients with HIV are co-infected with HCV and/or HBV because they share common risk factors for transmission (Quan et al., 1993; Zylberberg and Pol, 1996). HIV co-infected patients, especially those with markedly depressed CD4 $\mathrm{T}$ cell levels and AIDS, are known to have more aggressive liver disease with increased incidence of cirrhosis as compared to patients with controlled HIV or HCV/HBV monoinfection (Telfer et al., 1994; Darby et al., 1997). Because of the global impact of the AIDS pandemic in the 1980s a tremendous research effort has been invested in drug discovery for an ever expanding list of HIV targets. While mechanistic studies of HIV are not directly applicable to the hepatotrophic viruses per se, the large research effort that developed model systems for anti-HIV drug design forged a path that has facilitated drug discovery for hepatitis viruses.

The antiviral interactions of heme with HIV were investigated early after the virus was discovered. These experiments established that heme has the ability to inhibit reverse transcriptases (RT) such as Rauschermurine leukemia virus RT (Tsutsui and Mueller, 1987). Ensuing work (Levere et al., 1991) showed that heme administered alone or together with $3^{\prime}$-azido- $3^{\prime}$-deoxythymidine (AZT) was able to repress replication of HIV in human peripheral blood lymphocytes and $\mathrm{H} 9$ cell lines. This activity was found for both AZT-resistant and drug-sensitive HIV strains. Dose response studies showed significant antiviral activity at physiological levels of heme as low as $1 \mu \mathrm{M}$ and there was a clear, enhancing effect of heme in combination with AZT. Additional work from the same group demonstrated that heme was a non-competitive inhibitor of HIV-1 RT in contrast to classical competitive inhibition with deoxythymidine triphosphates (Staudinger et al., 1996). Some early structure-function relationships were also established from testing of heme analogs and other more diverse MP structures. Interestingly, the protoporphyrin structure was found to be crucial for anti-RT activity since metal meso derivatives were inactive.

Argyris et al. (1999) then identified a unique non-nucleoside inhibitory binding site for heme and putatively other MPs located in the connection domain (region 398-407 aa residues) of HIV1 and 2 RT. The site was revealed through heme binding assays matched to a phage-displayed 12 mer peptide library. Analysis of the peptides that actively bound heme showed that, as a group, they tended to be enriched in the aromatic amino acids Trp and Tyr while Cys residues were completely absent. There was synergism for RT inhibition with the unique heme binding site and another well-characterized non-nucleoside binding site located in the p66 palm sub domain (BHAP; Argyris et al., 1999). The authors speculated that the Tyr and Trp residues in this site of the enzyme 
facilitate heme binding through aromatic stacking with the planar porphyrin ring, while the propionyl and vinyl side chains anchor the holo heme.

The linear tetrapyrrole oxidation product of heme, biliverdin (BV), and its reduced derivative, bilirubin (BR) have also been reported to directly inhibit the HIV aspartic acid activated protease (McPhee et al., 1996). Using assays of recombinant HIV-1 protease, BV and BR showed nearly equal $K_{\mathrm{i}}$ values of about $1 \mu \mathrm{M}$ for HIV-1, 2, and simian immunodeficiency virus proteases. Related tetrapyrroles showed some antiprotease activity but at much higher concentrations. It should be emphasized that the inhibitory activities of BR and BV were noted to take place at near physiological concentrations of $\mathrm{BR}(17 \mu \mathrm{M}$ is $1.0 \mathrm{mg} / \mathrm{dl})$. Additionally, several synthetic boronated porphyrins also showed competitive inhibition of the HIV protease with $K_{\mathrm{i}}$ 's in the mid nanomolar range (Decamp et al., 1992).

\section{ANTI-HIV EFFECTS OF HO-1 INDUCTION ON HIV}

More recent work on the effects of heme on HIV replication demonstrated that heme also elicits antiviral activity through induction of HO-1 (Devadas and Dhawan, 2006). Heme was antiviral in vitro in a dosage dependent manner and elicited more than a $90 \%$ reduction of intracellular HIV in monocytes or T cells and was even active on drug resistant strains. While the heme antiviral targets that enabled these data were not specifically pursued, we can assume that heme likely worked through inhibition of viral uptake, RT inhibition, and/or inhibition of the HIV protease through heme oxidation products BV and BR as discussed above. An important point of this study is that it established that heme can attenuate viral levels in vivo. Intraperitoneal administration of heme attenuated HIV replication in humanized non-obese diabetic SCID mice carrying infected human PBMCs (Devadas and Dhawan, 2006).

\section{HEPATITIS B VIRUS}

Hepatitis B virus is the most common chronic viral pathogen worldwide. The virus is a member of the hepadnavirus family and is one of the smallest known pathogenic human DNA viruses of about $3.2 \mathrm{~kb}$. The virus replicates through a unique pre-genomic (pg) mRNA intermediate made by host nuclear enzymes which is then reverse transcribed into genomic DNA using a unique hepadnaviral reverse transcriptase. The reverse transcriptase of HBV shares a number of active site and substrate features with the HIV RT resulting in inhibitory drug overlap with HIV. However, hepadnaviral DNA synthesis employs a unique protein priming method for initiation of replication from pg RNA. The RT protein acts as both a protein primer and polymerase through interaction with a viral RNA structure (60 nucleotides) called $\in$ at the $5^{\prime}$ end of pg RNA. This complex facilitates origin of reverse transcription, packaging, and replication fidelity (Pollack and Ganem, 1994; Tavis et al., 1994; Wang et al., 1994). In contrast to both HIV and $\mathrm{HCV}$, replication and assembly of HBV occurs without a viral protease.

As compared to HIV and HCV, interactions of heme and heme oxygenase-1 with HBV have not been extensively evaluated. Nevertheless, HO-1 appears to be upregulated in response to chronic HBV infection as shown by immunohistochemical labeling of human liver samples (Abdalla et al., 2004). In a transgenic mouse model of acute and chronic HBV infection, Protzer et al. (2007) showed that induction of $\mathrm{HO}-1$ attenuated viral replication as determined by reduced levels of HBV core protein. In addition to virucidal activity, $\mathrm{HO}-1$ induction also led to reduced liver injury and hepato protective effects. The authors suggested that HO-1 induction worked posttranscriptionally to reduce the stability of HBV core protein (Protzer et al., 2007). Furthermore the combination of hepato protective effects from cellular injury and virucidal capabilities of HO-1 induction suggest additional benefits for potential antiviral drugs that could be designed using this important pathway.

Because heme was shown to have a specific inhibitory binding site on the HIV RT, we might predict that a similar interaction would occur with HBV. While recent evidence indicates that HBV replication is indeed inhibited by heme in vitro, at least one mechanism is decidedly different ( $\mathrm{Lin}$ and $\mathrm{Hu}, 2008$ ). Heme blocked the interaction of the RT protein with the $\epsilon$ segment of pg RNA, thus inhibiting the protein priming step of HBV replication. The heme binding site was localized to the N-terminal domain of the RT protein which is unique to hepadnaviral RT. In addition to heme, protoporphyrin free base and biliverdin were also active. While further studies of viral resistance, ligand specificity, and mechanism of these interactions need to be explored, these data suggest that similar compounds could be employed as either primary or adjunct therapy with nucleoside analogs for patients with chronic HBV infection.

\section{FINAL CONSIDERATIONS}

In spite of development of new and improved antiviral agents for HIV, HCV and HBV, there is a persistent and urgent need for new treatment modalities as well as combination therapies. Nearly all compounds developed against these pathogens have associated problems with toxicity, viral resistance, and selectivity (De Clercq, 2007; Firpi and Nelson, 2007; Zoulim, 2011) which makes ongoing discovery of new antivirals with improved clinical spectrum and versatility necessary.

Table 1 summarizes the various sites of antiviral activity of the precursors and products of the heme oxygenase- 1 system for all three viruses. It is apparent that the viral targets for heme are quite similar among the viruses in spite of viral diversity. All three viruses are inhibited by HO-1 induction and heme targets both HBV and HIV RT. Interestingly, however, heme RT inhibition occurs at different relative sites on the respective enzymes. Furthermore, heme, BV and BR inhibit both HIV and HCV proteases, in spite of the fact that the proteases differ markedly in primary structure, catalytic sites, and reaction mechanisms (Wlodawer et al., 1989; Love et al., 1996; Yan et al., 1998; Brik and Wong, 2003). Finally, HO1 induction offers protection from oxidative injury in HBV and $\mathrm{HCV}$ infection thus suggesting additional benefits against oxidative induced tissue injury that is considered to be a primary chronic disease mechanism leading to hepatic injury and fibrosis (Lieber, 1997; Lee et al., 2004; Qadri et al., 2004; Seronello et al., 2007).

Collectively, these findings indicate that heme and related porphyrins clearly should be considered for further in vivo translational studies, especially in suitable animal models and patient pilot trials, at least for proof-of-concept. The ability to inhibit 
Table 1 | Activities of heme and related agents for HCV, HBV, and HIV.

\begin{tabular}{|c|c|c|c|}
\hline Virus & Agent & Mechanism studied & Reference \\
\hline \multirow[t]{11}{*}{$\mathrm{HCV}$} & BV & Anti-NS3/4A protease & Zhu et al. (2010a) \\
\hline & BV & Type I interferon induction & Lehmann et al. (2010) \\
\hline & Heme & Anti-NS3/4A protease & Zhu et al. (2010a) \\
\hline & Heme & HO-1 induction & Shan et al. (2007), Zhu et al. (2008) \\
\hline & ZnMP & HO-1 induction and Bach 1 inhibition & Hou et al. (2008) \\
\hline & ZnMP & Ubiquitination of NS5A & Hou et al. (2010) \\
\hline & $\mathrm{Fe}$ & Antipolymerase & Fillebeen et al. (2005) \\
\hline & $\mathrm{Fe}$ & Decreased HCV replication & Yuasa et al. (2006), Zhu et al. (2010a) \\
\hline & $\mathrm{Fe}$ & HO-1 induction & Hou et al. (2009) \\
\hline & $\mathrm{Zn}$ & Decreased viral replication & Yuasa et al. (2006) \\
\hline & HO-1 enzyme & Enzyme overexpression & Zhu et al. (2008) \\
\hline \multirow[t]{2}{*}{ HBV } & Heme & Anti-reverse transcriptase & Lin and Hu (2008) \\
\hline & & HO-1 induction & Protzer et al. (2007) \\
\hline \multirow[t]{5}{*}{ HIV } & $\mathrm{BV} / \mathrm{BR}$ & Anti-HIV protease & McPhee et al. (1996) \\
\hline & Synthetic porphyrins & Anti-HIV protease & Decamp et al. (1992) \\
\hline & Heme/MPs & Anti-reverse transcriptase & Levere et al. (1991), Staudinger et al. (1996), Argyris et al. (1999) \\
\hline & $\mathrm{HO}-1$ induction & $\mathrm{HO}-1$ induction & Devadas and Dhawan (2006) \\
\hline & MPs & Gp120 inhibition & Song et al. (1997) \\
\hline
\end{tabular}

multiple viral target sites on different viruses indicates that these compounds would be also useful for patients with dual or even triple infections. Co-infected patients are a serious problem worldwide and invariably present with more severe medical disease, aggressive hepatitis, and a number of treatment dilemmas (den Brinker et al., 2000; Koziel and Peters, 2007; Zhou et al., 2011). Considering the antiviral fidelity of heme and products of the heme oxygenase system it is an open question as to the why these agents have not been developed further for antiviral therapy. Heme is proven to be efficacious for use in vivo for acute porphyria and is usually well tolerated. Further in vivo studies should focus on

\section{REFERENCES}

Abdalla, M. Y., Britigan, B. E., Wen, F., Icardi, M., McCormick, M. L., LaBrecque, D. R., Voigt, M., Brown, K. E., and Schmidt, W. N. (2004). Down-regulation of heme oxygenase- 1 by hepatitis $\mathrm{C}$ virus infection in vivo and by the in vitro expression of hepatitis C core protein. J. Infect. Dis. 190, 1109-1118.

Abraham, N. G., Lavrovsky, Y., Schwartzman, M. L., Stoltz, R. A., Levere, R. D., Gerritsen, M. E., Shibahara, S., and Kappas, A. (1995). Transfection of the human heme oxygenase gene into rabbit coronary microvessel endothelialcells - protective effect against heme and hemoglobin toxicity. Proc. Natl. Acad. Sci. U.S.A. 92, 6798-6802.

Argyris, E. G., Vanderkooi, J. M., Venkateswaran, P. S., Kay, B. K., and Paterson, Y. (1999). The connection domain is implicated in metalloporphyrin binding and inhibition of HIV reverse transcriptase. J. Biol. Chem. 274, 1549-1556.

Barresinoussi, F., Chermann, J. C., Rey, F., Nugeyre, M. T., Chamaret, S., Gruest, J., Dauguet, C., Axlerblin, C., Vezinetbrun, F., Rouzioux, C., Rozenbaum, W., and Montagnier, L. (1983). Isolation of a Tlymphotropic retrovirus from a patient at risk for acquired immunedeficiency syndrome (AIDS). Science 220, 868-871.

Bauer, I., Rensing, H., Florax, A., Ulrich, C., Pistorius, G., Redl, H., and Bauer, M. (2003). Expression pattern and regulation of heme oxygenase- 1 heat shock protein 32 in human liver cells. Shock 20, 116-122.

Beinker, N. K., Voigt, M. D., Arendse, M., Smit, J., Stander, I. A., and Kirsch, R. E. (1996). Threshold effect of liver

evaluation of porphyrin based antivirals with oral bioavailability, safety, and attractive pharmacodynamic capabilities to expand their use for HCV, HIV, and HBV infections.

\section{ACKNOWLEDGMENTS}

Supported in part by Merit Review grant from the Veterans Affairs (Warren N. Schmidt), University of Iowa Biological Sciences Funding Program of the University of Iowa (Warren N. Schmidt) an American Cancer Society Seed Award (Zhaowen Zhu) and the University of Iowa Doriann foundation for Hepatitis research.

iron content on hepatic inflammation and fibrosis in hepatitis B and C. J. Hepatol. 25, 633-638.

Benzaghou, I., Bougie, I., and Bisaillon, M. (2004). Effect of metal ion binding on the structural stability of the hepatitis C virus RNA polymerase. $J$. Biol. Chem. 279, 49755-49761.

Bissig, K. D., Le, T. T., Woods, N. B. and Verma, I. M. (2007). Repopulation of adult and neonatal mice with human hepatocytes: a chimeric animal model. Proc. Natl. Acad. Sci. U.S.A. 104, 20507-20511.

Bissig, K. D., Wieland, S. F., Tran, P., Isogawa, M., Le, T. T., Chisari, F. V., and Verma, I. M. (2010). Human liver chimeric mice provide a model for hepatitis $\mathrm{B}$ and $\mathrm{C}$ virus infection and treatment. J. Clin. Invest. 120 924-930.

Blight, K. J., McKeating, J. A., and Rice, C. M. (2002). Highly permissive cell lines for subgenomic and genomic hepatitis $\mathrm{C}$ virus RNA replication. J. Virol. 76, 13001-13014.

Bode, J. G., Brenndorfer, E. D., and Haussinger, D. (2007). Subversion of innate host antiviral strategies by the hepatitis $\mathrm{C}$ virus. Arch. Biochem. Biophys. 462, 254-265.

Bougie, I., Charpentier, S., and Bisaillon, M. (2003). Characterization of the metal ion binding properties of the hepatitis $\mathrm{C}$ virus RNA polymerase. $J$. Biol. Chem. 278, 3868-3875.

Brik, A., and Wong, C. H. (2003). HIV-1 protease: mechanism and drug discovery. Org. Biomol. Chem. 1, 5-14.

Cai, Z. H., Zhang, C., Chang, K. S., Jiang, J. Y., Ahn, B. C., Wakita, T., Liang, T. J., and Luo, G. X. (2005). Robust production of infectious hepatitis $\mathrm{C}$ virus (HCV) from stably $\mathrm{HCV}$ cDNA-transfected human hepatoma cells. J. Virol. 79, 13963-13973. 
Casteel, M. J., Jayaraj, K., Gold, A., Ball, L. M., and Sobsey, M. D. (2004). Photoinactivation of hepatitis A virus by synthetic porphyrins. Photochem. Photobiol. 80, 294-300.

Castet, V., Fournier, C., Soulier, A., Brillet, R., Coste, J., Larrey, D., Dhumeaux, D., Maurel, P., and Pawlotsky, J. M. (2002). Alpha interferon inhibits hepatitis $\mathrm{C}$ virus replication in primary human hepatocytes infected in vitro. J. Virol. 76, 8189-8199.

Cheng, G., Zhong, J., Chung, J., and Chisari, F. V. (2007). Doublestranded DNA and double-stranded RNA induce a common antiviral signaling pathway in human cells. Proc. Natl. Acad. Sci. U.S.A. 104, 9035-9040.

Cheng, Y., Tsou, L. K., Cai, J., Aya, T., Dutschman, G. E., Gullen, E. A., Grill, S. P., Chen, A. P., Lindenbach, B. D., Hamilton, A. D., and Cheng, Y. C. (2010). A novel class of meso-tetrakis-porphyrin derivatives exhibits potent activities against hepatitis $\mathrm{C}$ virus genotype $1 \mathrm{~b}$ replicons in vitro. Antimicrob. Agents Chemother. 54, 197-206.

Cruse, I., and Maines, M. D. (1988). Evidence suggesting that the two forms of heme oxygenase are products of different genes. J. Biol. Chem. 263, 3348-3353.

Darby, S. C., Ewart, D. W., Giangrande, P. L. F., Spooner, R. J. D., Rizza, C. R., Dusheiko, G. M., Lee, C. A., Ludlam, C. A., and Preston, F. E. (1997). Mortality from liver cancer and liver disease in haemophilic men and boys in UK given blood products contaminated with hepatitis C. Lancet 350, 1425-1431.

De Clercq, E. (2007). The design of drugs for HIV and HCV. Nat. Rev. Drug Discov. 6, 1001-1018.

de Jong, Y. P., Rice, C. M., and Ploss, A. (2010). New horizons for studying human hepatotropic infections. J. Clin. Invest. 120, 650-653.

Debnath, A. K., Jiang, S., Strick, N., Lin, K., Haberfield, P., and Neurath, A. R. (1994). 3-Dimensional structureactivity analysis of a series of porphyrin derivatives with anti-HIV1 activity targeted to the V3 loop of the gp120 envelope glycoprotein of the human-immunodeficiencyvirus type-1. J. Med. Chem. 37, 1099-1108.

Debnath, A. K., Jiang, S. B., Strick, N., Lin, K., Kahl, S. B., and Neurath, A. R. (1999). Anti-HIV-1 activity of carborane derivatives of porphyrins. Med. Chem. Res. 9, 267-275.

Decamp, D. L., Babe, L. M., Salto, R., Lucich, J. L., Koo, M. S., Kahl,
S. B., and Craik, C. S. (1992). Specific-inhibition of HIV-1 protease by boronated porphyrins. J. Med. Chem. 35, 3426-3428.

den Brinker, M., Wit, F. W. N. M. Wertheim-van Dillen, P. M. E., Jurriaans, S., Weel, J., van Leeuwen, R., Pakker, N. G., Reiss, P., Danner, S. A., Weverling, G. J., and Lange, J. M. A. (2000). Hepatitis B and C virus co-infection and the risk for hepatotoxicity of highly active antiretroviral therapy in HIV-1 infection. AIDS 14, 2895-2902.

Desai, T. K., Jamil, L. H., Balasubramaniam, M., Koff, R., and Bonkovsky, H. L. (2008). Phlebotomy improves therapeutic response to interferon in patients with chronic hepatitis C: a meta-analysis of six prospective randomized controlled trials. Dig. Dis. Sci. 53, 815-822.

Devadas, K., and Dhawan, S. (2006). Hemin activation ameliorates HIV1 infection via heme oxygenase1 induction. J. Immunol. 176, 4252-4257.

Di Bisceglie, A. M., Bonkovsky, H. L., Chopra, S., Flamm, S., Reddy, R. K., Grace, N., Killenberg, P., Hunt, C., Tamburro, C., Tavill, A. S., Ferguson, R., Krawitt, E., Banner, B., and Bacon, B. R. (2000). Iron reduction as an adjuvant to interferon therapy in patients with chronic hepatitis $\mathrm{C}$ who have previously not responded to interferon: a multicenter, prospective, randomized, controlled trial. Hepatology 32, 135-138.

Ferrari, E., Wright-Minogue, J., Fang, J. W. S., Baroudy, B. M., Lau, J. Y. N., and Hong, Z. (1999). Characterization of soluble hepatitis $\mathrm{C}$ virus RNA-dependent RNA polymerase expressed in Escherichia coli. J. Virol. 73, 1649-1654.

Fillebeen, C., Muckenthaler, M., Andricipoulos, B., Bisaillon, M., Mounir, Z., Hentze, M. W., Koromilas, A. E., and Pantopoulos, K. (2007). Expression of the subgenomic hepatitis $\mathrm{C}$ virus replicon alters iron homeostasis in Huh7 cells. J. Hepatol. 47, 12-22.

Fillebeen, C., Rivas-Estilla, A. M., Bisaillon, M., Ponka, P., Muckenthaler, M., Hentze, M. W., Koromilas, A. E., and Pantopoulos, K. (2005). Iron inactivates the RNA polymerase NS5B and suppresses subgenomic replication of hepatitis C Virus. J. Biol. Chem. 280, 9049-9057.

Firpi, R. J., and Nelson, D. R. (2007). Current and future hepatitis $\mathrm{C}$ therapies. Arch. Med. Res. 38, 678-690.

Fontana, R. J., Israel, J., LeClair, P., Banner, B. F., Tortorelli, K., Grace, N., Levine, R. A., Fiarman, G., Thiim,
M., Tavill, A. S., and Bonkovsky, H. L. (2000). Iron reduction before and during interferon therapy of chronic hepatitis C: results of a multicenter, randomized, controlled trial. Hepatology 31, 730-736.

Gibbs, P. E., and Maines, M. D. (2007). Biliverdin inhibits activation of NFkappaB: reversal of inhibition by human biliverdin reductase. Int. J. Cancer 121, 2567-2574.

Gibbs, P. E. M., Miralem, T., and Maines, M. D. (2010). Characterization of the human biliverdin reductase gene structure and regulatory elements: promoter activity is enhanced by hypoxia and suppressed by TNFalpha-activated NF-kappa B. FASEB J. 24, 3239-3254.

Gondeau, C., Pichard-Garcia, L., and Maurel, P. (2009). Cellular models for the screening and development of anti-hepatitis C virus agents. Pharmacol. Ther. 124, 1-22.

Gozzelino, R., Jeney, V., and Soares, M. P. (2010). Mechanisms of cell protection by heme oxygenase-1. Annu. Rev. Pharmacol. 50, 323-354.

Gray, H. B., and Winkler, J. R. (1996). Electron transfer in proteins. Annu. Rev. Biochem. 65, 537-561.

Guo, H. T., Pan, X. B., Mao, R. C., Zhang, X. C., Wang, L. J., Lu, X. Y., Chang, J. H., Guo, J. T., Passic, S., Krebs, F. C. Wigdahl, B., Warren, T. K., Retterer, C. J., Bavari, S., Xu, X. D., Cuconati, A., and Block, T. M. (2011) Alkylated porphyrins have broad antiviral activity against hepadnaviruses, flaviviruses, filoviruses, and arenaviruses. Antimicrob. Agents Chemother. 55, 478-486.

Guo, X., Shin, V. Y., and Cho, C. H. (2001). Modulation of heme oxygenase in tissue injury and its implication in protection against gastrointestinal diseases. Life Sci. 69, 3113-3119.

Hayashi, S., Omata, Y., Sakamoto, H. Higashimoto, Y., Hara, T., Sagara, Y., and Noguchi, M. (2004). Characterization of rat heme oxygenase- 3 gene. Implication of processed pseudogenes derived from heme oxygenase2 gene. Gene 336, 241-250.

Heinemann, I. U., Jahn, M., and Jahn, D. (2008). The biochemistry of heme biosynthesis. Arch. Biochem. Biophys. 474, 238-251.

Hou, W., Tian, Q., Zheng, J., and Bonkovsky, H. L. (2010). Zinc mesoporphyrin induces rapid proteasomal degradation of hepatitis $\mathrm{C}$ nonstructural $5 \mathrm{~A}$ protein in human hepatoma cells. Gastroenterology 138, 1909-1919.

Hou, W. H., Rossi, L., Shan, Y., Zheng, J. Y., Lambrecht, R. W. and Bonkovsky, H. L. (2009). Iron increases HMOX1 and decreases hepatitis $\mathrm{C}$ viral expression in $\mathrm{HCV}$ expressing cells. World J. Gastroenterol. 15, 4499-4510.

Hou, W. H., Shan, Y., Zheng, J. Y., Larnbrecht, R. W., Donohue, S. E., and Bonkovsky, H. L. (2008). Zinc mesoporphyrin induces rapid and marked degradation of the transcription factor Bachl and upregulates HO-1. Biochim. Biophys. Acta 1779, 195-203.

Immenschuh, S., and Ramadori, G. (2000). Gene regulation of heme oxygenase- 1 as a therapeutic target. Biochem. Pharmacol. 60, 1121-1128.

Kalliolias, G. D., and Ivashkiv, L. B. (2010). Overview of the biology of type I interferons. Arthritis Res. Ther. 12(Suppl. 1), S1.

Kapitulnik, J., and Maines, M. D. (2009). Pleiotropic functions of biliverdin reductase: cellular signaling and generation of cytoprotective and cytotoxic bilirubin. Trends Pharmacol. Sci. 30, 129-137.

Kato, T., Date, T., Miyamoto, M., Furusaka, A., Tokushige, K., Mizokami, M., and Wakita, T. (2003). Efficient replication of the genotype $2 \mathrm{a}$ hepatitis $\mathrm{C}$ virus subgenomic replicon. Gastroenterology 125, 1808-1817.

Kayali, Z., Ranguelov, R., Mitros, F., Shufelt, C., Elmi, F., Rayhill, S. C., Schmidt, W. N., and Brown, K. E. (2005). Hemosiderosis is associated with accelerated decompensation and decreased survival in patients with cirrhosis. Liver Int. 25, 41-48.

Kayali, Z., Tan, S., Shinkunas, L., Voigt, M., LaBrecque, D. R., Stapleton, J. T., Brown, K. E., and Schmidt, W. N. (2007). Risk factors for hepatitis C fibrosis: a prospective study of United States veterans compared with nonveterans. J. Viral Hepat. 14, 11-21.

Khvalevsky, E., Rivkin, L., Rachmilewitz, J., Galun, E., and Giladi, H. (2007). TLR3 signaling in a hepatoma cell line is skewed towards apoptosis. $J$. Cell. Biochem. 100, 1301-1312.

Kitamuro, T., Takahashi, K., Ogawa, K., Udono-Fujimori, R., Takeda, K., Furuyama, K., Nakayama, M., Sun, J. Y., Fujita, H., Hida, W., Hattori, T., Shirato, K., Igarashi, K., and Shibahara, S. (2003). Bach1 functions as a hypoxia-inducible repressor for the heme oxygenase-1 gene in human cells. J. Biol. Chem. 278, 9125-9133.

Koliaraki, V., and Kollias, G. (2011). A new role for myeloid $\mathrm{HO}-1$ in the innate to adaptive crosstalk 
and immune homeostasis. Adv. Exp. Med. Biol. 780, 101-111.

Koziel, M. J., and Peters, M. G. (2007). Viral hepatitis in HIV infection. $N$. Engl. J. Med. 356, 1445-1454.

Labbe, R. F. (1992). Clinical utility of zinc protoporphyrin. Clin. Chem. 38, 2167-2168.

Lee, P. J., Alam, J., Wiegand, G. W., and Choi, A. M. K. (1996). Overexpression of heme oxygenase-1 in human pulmonary epithelial cells results in cell growth arrest and increased resistance to hyperoxia. Proc. Natl. Acad. Sci. U.S.A. 93, 10393-10398.

Lee, Y. I., Hwang, J. M., Im, J. H., Lee, Y. I., Kim, N. S., Kim, D. G., Yu, D. Y., Moon, H. B., and Park, S. K. (2004). Human hepatitis $B$ virus-X protein alters mitochondrial function and physiology in human liver cells. J. Biol. Chem. 279, 15460-15471.

Lehmann, E., El-Tantawy, W. H., Ocker, M., Bartenschlager, R., Lohmann, V., Hashemolhosseini, S., Tiegs, G., and Sass, G. (2010). The heme oxygenase 1 product biliverdin interferes with hepatitis $\mathrm{C}$ virus replication by increasing antiviral interferon response. Hepatology 51, 398-404.

Lemon, S. M., Murphy, P. C., Smith, A., Zou, J. S., Hammon, J., Robinson, S., and Horowitz, B. (1994). Removal/neutralization of hepatitisa virus during manufacture of highpurity, solvent/detergent factor-Viii concentrate. J. Med. Virol. 43, 44-49.

Levere, R. D., Gong, Y. F., Kappas, A., Bucher, D. J., Wormser, G. P., and Abraham, N. G. (1991). Heme inhibits human immunodeficiency virus 1 replication in cell cultures and enhances the antiviral effect of zidovudine. Proc. Natl. Acad. Sci. U.S.A. 88, 1756-1759.

Li, K., Chen, Z. H., Kato, N., Gale, M., and Lemon, S. M. (2005a). Distinct poly (I-C) and virusactivated signaling pathways leading to interferon-beta production in hepatocytes. J. Biol. Chem. 280, 16739-16747.

Li, K., Foy, E., Ferreon, J. C., Nakamura, M., Ferreon, A. C. M., Ikeda, M., Ray, S. C., Gale, M., and Lemon, S. M. (2005b). Immune evasion by hepatitis C virus NS3/4A proteasemediated cleavage of the Toll-like receptor 3 adaptor protein TRIF. Proc. Natl. Acad. Sci. U.S.A. 102, 2992-2997.

Lieber, C. S. (1997). Role of oxidative stress and antioxidant therapy in alcoholic and nonalcoholic liver diseases. Adv. Pharmacol. 38, 601-628.
Lin, L., and Hu, J. (2008). Inhibition of hepadnavirus reverse transcriptaseepsilon RNA interaction by porphyrin compounds. J. Virol. 82, 2305-2312.

Lindenbach, B. D., and Rice, C. M. (2005). Unravelling hepatitis C virus replication from genome to function. Nature 436, 933-938.

Lohmann, V., Korner, F., Koch, J. O., Herian, U., Theilmann, L., and Bartenschlager, R. (1999). Replication of subgenomic hepatitis $\mathrm{C}$ virus RNAs in a hepatoma cell line. Science 285, 110-113.

Loo, Y. M., Owen, D. M., Li, K., Erickson, A. K., Johnson, C. L., Fish, P. M., Carney, D. S., Wang, T., Ishida, H., Yoneyama, M., Fujita, T., Saito, T., Lee, W. M., Hagedorn, C. H., Lau, D. T., Weinman, S. A., Lemon, S. M., and Gale, M. Jr. (2006). Viral and therapeutic control of IFN-beta promoter stimulator 1 during hepatitis C virus infection. Proc. Natl. Acad. Sci. U.S.A. 103, 6001-6006.

Love, R. A., Parge, H. E., Wickersham, J. A., Hostomsky, Z., Habuka, N., Moomaw, E. W., Adachi, T., and Hostomska, Z. (1996). The crystal structure of hepatitis C virus NS3 proteinase reveals a trypsin-like fold and a structural zinc binding site. Cell 87, 331-342.

Makino, N., Suematsu, M., Sugiura, Y., Morikawa, H., Shiomi, S., Goda, N., Sano, T., Nimura, Y., Sugimachi, K., and Ishimura, Y. (2001). Altered expression of heme oxygenase- 1 in the livers of patients with portal hypertensive diseases. Hepatology $33,32-42$.

McCoubrey, W. K., Huang, T. J., and Maines, M. D. (1997). Heme oxygenase- 2 is a hemoprotein and binds heme through heme regulatory motifs that are not involved in heme catalysis. J. Biol. Chem. 272, 12568-12574.

McDonagh, A. F. (2001). Turning green to gold. Nat. Struct. Biol. 8, 198-200.

McPhee, F., Caldera, P. S., Bemis, G. W., McDonagh, A. F., Kuntz, I. D., and Craik, C. S. (1996). Bile pigments as HIV-1 protease inhibitors and their effects on HIV-1 viral maturation and infectivity in vitro. Biochem. J. 320, 681-686.

Mense, S. M., and Zhang, L. (2006). Herne: a versatile signaling molecule controlling the activities of diverse regulators ranging from transcription factors to MAP kinases. Cell Res. $16,681-692$.

Meylan, E., Curran, J., Hofmann, K., Moradpour, D., Binder, M., Bartenschlager, R., and Tschopp, R. (2005). Cardif is an adaptor protein in the
RIG-I antiviral pathway and is targeted by hepatitis C virus. Nature 437, 1167-1172.

Nogales, D., and Lightner, D. A. (1995). On the structure of bilirubin in solution - C-13 (H-1) heteronuclear Overhauser effect NMR analyses in aqueous buffer and organicsolvents. J. Biol. Chem. 270, 73-77.

Ogawa, K., Sun, J., Taketani, S., Nakajima, O., Nishitani, C., Sassa, S., Hayashi, N., Yamamoto, M., Shibahara, S., Fujita, H., and Igarashi, K. (2001). Heme mediates derepression of Maf recognition element through direct binding to transcription repressor Bach1. EMBO J. 20, 2835-2843.

Ollinger, R., Wang, H., Yamashita, K., Wegiel, B., Thomas, M., Margreiter, R., and Bach, F. H. (2007). Therapeutic applications of bilirubin and biliverdin in transplantation. Antioxid. Redox Signal. 9, 2175-2185.

Pietschmann, T., Lohmann, V., Rutter, G., Kurpanek, K., and Bartenschlager, R. (2001). Characterization of cell lines carrying self-replicating hepatitis C virus RNAs. J. Virol. 75, 1252-1264.

Pollack, J. R., and Ganem, D. (1994). Site-specific RNA-binding by a hepatitis-B virus reversetranscriptase initiates 2 distinct reactions - RNA packaging and DNA-synthesis. J. Virol. 68, 5579-5587.

Popovic, M., Sarngadharan, M. G. Read, E., and Gallo, R. C. (1984). Detection, isolation, and continuous production of cytopathic retroviruses (HTLV-III) from patients with AIDS and pre-AIDS. Science 224, 497-500.

Protzer, U., Seyfried, S., Quasdorff, M., Sass, G., Svorcova, M., Webb, D., Bohne, F., Hosel, M., Schirmacher, P., and Tiegs, G. (2007). Antiviral activity and hepatoprotection by heme oxygenase-1 in hepatitis B virus infection. Gastroenterology 133, 1156-1165.

Qadri, I., Iwahashi, M., Capasso, J. M., Hopken, M. W., Flores, S., Schaack, J., and Simon, F. R. (2004). Induced oxidative stress and activated expression of manganese superoxide dismutase during hepatitis $\mathrm{C}$ virus replication: role of JNK, p38 MAR and AP-1. Biochem. J. 378, 919-928.

Qin, X. (2007). Inactivation of digestive proteases by deconjugated bilirubin: the possible evolutionary driving force for bilirubin or biliverdin predominance in animals. Gut 56, 1641-1642.
Quan, C. M., Krajden, M., Grigoriew, G. A., and Salit, I. E. (1993). Hepatitis-C virus-infection in patients infected with the humanimmunodeficiency-virus. Clin. Infect. Dis. 17, 117-119.

Ryter, S. W., Alam, J., and Choi, A. M. K. (2006). Heme oxygenase$1 /$ carbon monoxide: from basic science to therapeutic applications. Physiol. Rev. 86, 583-650.

Ryter, S. W., and Tyrrell, R. M. (2000). The Heme synthesis and degradation pathways: role in oxidant sensitivity - heme oxygenase has both pro- and antioxidant properties. Free Radic. Biol. Med. 28, 289-309.

Seronello, S., Sheikh, M. Y., and Choi, J. (2007). Redox regulation of hepatitis C in nonalcoholic and alcoholic liver. Free Radic. Biol. Med. 43, 869-882.

Shan, Y., Zheng, J., Lambrecht, R. W., and Bonkovsky, H. L. (2007). Reciprocal effects of micro-RNA-122 on expression of heme oxygenase- 1 and hepatitis $\mathrm{C}$ virus genes in human hepatocytes. Gastroenterology 133, 1166-1174.

Song, R., Witvrouw, M., Schols, D., Robert, A., Balzarini, J., DeClercq, E. Bernadou, J., and Meunier, B. (1997) Anti-HIV activities of anionic metalloporphyrins and related compounds. Antivir. Chem. Chemother. 8, 85-97.

Soriano, V., Peters, M. G., and Zeuzem, S. (2009). New therapies for hepatitis $\mathrm{C}$ virus infection. Clin. Infect. Dis. 48, 313-320.

Staudinger, R., Abraham, N. G., Levere, R. D., and Kappas, A. (1996). Inhibition of human immunodeficiency virus-1 reverse transcriptase by heme and synthetic heme analogs. Proc. Assoc. Am. Physicians 108, 47-54.

Stojiljkovic, I., Evavold, B. D., and Kumar, V. (2001). Antimicrobial properties of porphyrins. Expert Opin. Investig. Drugs 10, 309-320.

Tavis, J. E., Perri, S., and Ganem, D. (1994). Hepadnavirus reverse transcription initiates within the stemloop of the RNA packaging signal and employs a novel strand transfer. J. Virol. 68, 3536-3543.

Telfer, P., Sabin, C., Devereux, H., Scott, F., Dusheiko, G., and Lee, C. (1994). The progression of $\mathrm{HCV}$-associated liver-disease in a cohort of hemophilic patients. Br. J. Haematol. 87, 555-561.

Tsutsui, K., and Mueller, G. C. (1987). Hemin inhibits virion-associated reverse-transcriptase of murine leukemia-virus. Biochem. Biophys. Res. Commun. 149, 628-634. 
Tzima, S., Victoratos, P., Kranidioti, K., Alexiou, M., and Kollias, G. (2009). Myeloid heme oxygenase-1 regulates innate immunity and autoimmunity by modulating IFN-beta production. J. Exp. Med. 206, 1167-1179.

Wakita, T., Pietschmann, T., Kato, T., Date, T., Miyamoto, M., Zhao, Z. J., Murthy, K., Habermann, A., Krausslich, H. G., Mizokami, M., Bartenschlager, R., and Liang, T. J. (2005). Production of infectious hepatitis $\mathrm{C}$ virus in tissue culture from a cloned viral genome. Nat. Med. 11, 791-796.

Wang, G. H., Zoulim, F., Leber, E. H., Kitson, J., and Seeger, C. (1994). Role of RNA in enzymaticactivity of the reverse-transcriptase of hepatitis-B viruses. J. Virol. 68, 8437-8442.

Washburn, M. L., Bility, M. T., Zhang, L. G., Kovalev, G. I., Buntzman, A., Frelinger, J. A., Barry, W., Ploss, A., Rice, C. M., and Su, L. S. (2011). A humanized mouse model to study hepatitis $\mathrm{C}$ virus infection, immune response, and liver disease. Gastroenterology 140, 1334-1344.

Wlodawer, A., Miller, M., Jaskolski, M., Sathyanarayana, B. K., Baldwin, E., Weber, I. T., Selk, L. M., Clawson,
L., Schneider, J., and Kent, S. B. H. (1989). Conserved folding in retroviral proteases - crystal-structure of a synthetic HIV-1 protease. Science 245, 616-621.

Yan, Y. W., Li, Y., Munshi, S., Sardana, V., Cole, J. L., Sardana, M., Steinkuehler, C., Tomei, L., De Francesco, R., Kuo, L. C., and Chen, Z. G. (1998). Complex of NS3 protease and NS4A peptide of $\mathrm{BK}$ strain hepatitis $\mathrm{C}$ virus: $\mathrm{A}$ 2.2 angstrom resolution structure in a hexagonal crystal form. Protein Sci. 7, 837-847.

Yuasa, K., Naganuma, A., Sato, K. Ikeda, M., Kato, N., Takagi, H., and Mori, M. (2006). Zinc is a negative regulator of hepatitis $\mathrm{C}$ virus RNA replication. Liver Int. 26, 1111-1118.

Zhou, Y. H., Liu, F. L., Yao, Z. H., Duo, L., Li, H., Sun, Y., and Zheng, Y. T. (2011). Comparison of HIV-, HBV-, HCV- and coinfection prevalence between Chinese and Burmese intravenous drug users of the China-Myanmar border region. PLoS ONE 6, e16349. doi:10.1371/journal.pone.0016349

Zhu, Z., Wilson, A. T., Luxon, B. A. Brown, K. E., Mathahs, M. M., Bandyopadhyay, S., McCaffrey, A.
P., and Schmidt, W. N. (2010a) Biliverdin inhibits hepatitis $\mathrm{C}$ virus nonstructural $3 / 4 \mathrm{~A}$ protease activity: mechanism for the antiviral effects of heme oxygenase? Hepatology 52 , 1897-1905.

Zhu, Z. W., Wilson, A. T., Gopalakrishna, K., Brown, K. E., Luxon, B. A., and Schmidt, W. N. (2010b). Hepatitis C virus core protein enhances telomerase activity in Huh7 cells. J. Med. Virol. 82, 239-248.

Zhu, Z., Wilson, A. T., Mathahs, M. M., Wen, F., Brown, K. E., Luxon, B. A., and Schmidt, W. N. (2008) Heme oxygenase-1 suppresses hepatitis $\mathrm{C}$ virus replication and increases resistance of hepatocytes to oxidant injury. Hepatology 48, 1430-1439.

Zhu, Z. W., Mathahs, M. M., and Schmidt, W. N. (2011). Biliverdin and heme restore type I interferon expression in cells expressing HCV NS3/4a protease. Hepatology 54, 541a.

Zoulim, F. (2011). Hepatitis B virus resistance to antiviral drugs: where are we going? Liver Int. 31, 111-116. Zylberberg, H., and Pol, S. (1996). Reciprocal interactions between human immunodeficiency virus and hepatitis C virus infections. Clin. Infect. Dis. 23, 1117-1125.

Conflict of Interest Statement: The authors declare that the research was conducted in the absence of any commercial or financial relationships that could be construed as a potential conflict of interest.

Received: 15 February 2012; accepted: 18 June 2012; published online: 04 October 2012.

Citation: Schmidt WN, Mathahs MM and $Z h u ~ Z$ (2012) Heme and HO1 inhibition of $\mathrm{HCV}, \mathrm{HBV}$, and HIV. Front. Pharmacol. 3:129. doi 10.3389/fphar.2012.00129

This article was submitted to Frontiers in Drug Metabolism and Transport, a specialty of Frontiers in Pharmacology. Copyright (c) 2012 Schmidt, Mathahs and Zhu. This is an open-access article distributed under the terms of the Creative Commons Attribution License, which permits use, distribution and reproduction in other forums, provided the original authors and source are credited and subject to any copyright notices concerning any third-party graphics etc. 